\title{
Milhares de comunidades sem eucaristia interpelam o Sínodo da Amazônia
}

\section{Thousands of communities without eucharist challenge}

the Synod of the Amazon

ANTÔNIO JOSÉ DE ALMEIDA ${ }^{\mathrm{a}}$

\section{Resumo}

O texto parte da constatação de que milhares de comunidades católicas na região amazônica só esporadicamente podem participar da celebração da Eucaristia, devido às distâncias e à falta de presbíteros próprios que vivam nas comunidades dispersas pelo imenso território. Reconhece que esta situação é teologicamente anômala, pois a celebração da Eucaristia é essencial para a construção da Igreja como Corpo de Cristo. Sugere que as comunidades católicas formadas pela Palavra de Deus em suas várias modalidades, especialmente a sua Celebração dominical, com uma boa caminhada eclesial, já dotadas de ministérios não-ordenados vários, sejam munidas de presbíteros próprios, que, devidamente ordenados, presidam, com uma equipe ministerial mais ampla, a comunidade e, consequentemente, a Eucaristia comunitária. O Sínodo, no Instrumento Preparatório, mostra-se consciente desta realidade e, no Instrumento de Trabalho, faz duas indicações preciosas: a) "pede-se que, em vez de deixar as comunidades sem a Eucaristia, se alterem os critérios para selecionar e preparar os ministros autorizados para celebrá-la"; b) "pede-se que, para as áreas mais remotas da região, se estude a possibilidade da ordenação sacerdotal de anciãos, de preferência indígenas, respeitados e reconhecidos por suas comunidades, mesmo que tenham uma família constituída e estável, com a finalidade de assegurar os Sacramentos que acompanhem e sustentem a vida cristã" (n. 126 e 129). Explicitar os fundamentos (sobretudo a relação Eucaristia-Igreja e Igreja-Eucaristia) e detalhar propostas nesta direção são os objetivos desta reflexão.

\footnotetext{
a Diocese de Apucarana. Doutor em Teologia, e-mail: ajacatedral@uol.com.br
} 
Palavras-chave: Comunidade. Eucaristia. Ministérios. Direito "da graça". Direito da "legislação".

\section{Abstract}

The text comes from the realization that thousands of Catholic communities in the Amazon region can only participate sporadically in the celebration of the Eucharist, due to the distances and lack of their own elders who live in communities scattered throughout the vast territory. It recognizes that this situation is theologically anomalous, since the celebration of the Eucharist is essential for the construction of the Church as the Body of Christ. Suggests that the Catholic communities formed by the Word of God in their various forms, especially their Sunday Celebration, with a good ecclesial walk, already endowed with various unordered ministries, should be provided with their own priests, who, properly ordained, preside with a wider ministerial team, the community and, consequently, the communal Eucharist. The Synod, in the Preparatory Instrument, is conscious of this reality and, in the Working Instrument, makes two precious indications: a) "Instead of leaving communities without the Eucharist, we ask that the criteria for selecting and prepare the ministers authorized to celebrate it "; b) "it is requested that, for the most remote areas of the region, the possibility of priestly ordination of elders, preferably indigenous, respected and recognized by their communities, even if they have a constituted and stable family, be studied, with the purpose of to assure the sacraments that accompany and sustain the Christian life" (n. 126 and 129). Explaining the fundamentals (especially the relationship between the Eucharist-Church and the Church-Eucharist) and detailing proposals in this direction are the objectives of this reflection.

Keywords: Community. Eucharist. Ministries. Right "of grace". Right "of law".

\section{Introdução}

O Sínodo Especial para a Amazônia (Roma, outubro de 2019) vai abordar, entre outras, a questão das milhares de comunidades que não podem celebrar a eucaristia não só aos domingos, mas, muitas vezes, só a cada seis meses, a cada ano ou até dois, por falta de presbíteros.

Muitas dessas comunidades são alimentadas regularmente pela Celebração da Palavra de Deus. Mas não podem parar aí. Embora a Celebração da Palavra faça, a seu modo, memória do mistério pascal de Cristo, morto e ressuscitado, "deve-se lembrar que essa celebração - que tem um valor próprio e responde a uma necessidade pastoral premente entre nós — não 
pode, em hipótese alguma, obscurecer o valor único e inigualável da Celebração da Eucaristia" (CNBB, 2019, n. 41).

O presente estudo visa justamente a examinar a centralidade da Eucaristia na conformação da comunidade; a assembleia eucarística como sujeito integral da celebração da eucaristia e o presidente da comunidade como presidente da eucaristia; a proposta de uma solução para as milhares de comunidades católicas que, na região amazônica, só esporadicamente podem celebrar a eucaristia.

\section{A Eucaristia faz a igreja}

A Igreja, como sabemos, é criatura da Palavra (creatura Verbi), mas igual e indissoluvelmente, da Eucaristia (ab Eucharistiae mysterio). A primeira afirmação ganhou relevo na obra de Lutero, mas não é uma tese luterana; a Igreja católica confessional a compartilha (MAFFEIS, 2012). A segunda é doutrina da Igreja indivisa do primeiro milênio e, no âmbito da teologia, foi ampla e profundamente estudada por De Lubac, que cunhou o famoso axioma “A Igreja faz a eucaristia, e a eucaristia faz a Igreja” (CANOBBIO, 2012).

Quando se fala da eucaristia, fala-se - e isso precisa ficar muito claro em primeiro lugar e essencialmente, da "celebração" da eucaristia, em seu sentido pleno:

\footnotetext{
O nosso Salvador instituiu na última Ceia, na noite em que foi entregue, o sacrifício eucarístico do seu Corpo e do seu Sangue para perpetuar pelo decorrer dos séculos, até ele voltar, o sacrifício da cruz, confiando à Igreja, sua esposa amada, o memorial da sua morte e ressurreição: sacramento de piedade, sinal de unidade, vínculo de caridade, banquete pascal em que se recebe Cristo, a alma se enche de graça e nos é concedido o penhor da glória futura (SC 47).
}

Não se está falando da reserva eucarística nem das diversas manifestações de culto ou piedade eucarística - comunhão fora da missa, adoração ao Santíssimo, bênção do Santíssimo, procissão de Corpus Christi, etc. - que têm seu sentido a partir e em conexão com a celebração, mas não equivalem nem substituem a celebração. Infelizmente, em função da disputa entre "simbolistas" e "fisicalistas" sobre a presença de Cristo na eucaristia ("crise berengariana" ou "controvérsia eucarística"), na passagem do primeiro para o segundo milênio, o eixo da prática da eucaristia se deslocou da 
celebração da eucaristia para o culto eucarístico, do sentido pleno da eucaristia para o aspecto, legítimo, sem dúvida, mas sempre relativo à celebração, da presença real.

No primeiro milênio e ao longo da Idade Média, não houve, a não ser muito excepcionalmente, comunidades sem celebração da eucaristia e, portanto, comunidades sem sacerdote, que - presidindo, via de regra, a inteira comunidade - presidia também a eucaristia da comunidade (LEGRAND, 1977). O problema de comunidades sem eucaristia é um problema moderno, que surgiu em áreas missionárias de cultura não europeia, nas quais a Igreja não conseguia dotar suficientemente de clero próprio, e que os missionários não tinham condições físicas de atender devidamente em áreas territorialmente extensas e com grandes dificuldades de transporte e comunicação. Em alguns países ou regiões isto se tornou um problema crônico. No Brasil, por exemplo, consta que 70.000 comunidades não celebram a Eucaristia com a frequência devida, que, rigorosamente, seria dominical: "A celebração dominical do Dia e da Eucaristia do Senhor está no coração da vida da Igreja. "O domingo, dia em que por tradição apostólica se celebra o Mistério Pascal, deve ser guardado em toda a Igreja como dia de festa de preceito por excelência" (CATECISMO DA IGREJA CATÓLICA, n. 2177).

A questão não é o esvaziamento das comunidades, a falta de fé na eucaristia, o baixo apreço por sua celebração. O problema, que se arrasta por séculos, é a falta de quem presida, em nome de Cristo, a eucaristia.

\subsection{A Igreja faz a Eucaristia}

Da reflexão feita a partir do tópico anterior é que se impõe a primeira pregunta: "quem faz a eucaristia" ou "quem celebra a eucaristia"? A resposta corrente, que brota imediata e espontânea, é "o padre", ou "o sacerdote", ou “o presbítero". A esta pergunta, porém, a resposta unânime, quer nos textos do Novo Testamento, quer nos textos dos primeiros escritores cristãos, é clara: a Igreja. "Antes de mais nada, a ceia do Senhor é um ato da comunidade inteira: seja qual for a sua condição social, os fiéis se reúnem regularmente para uma ceia fraterna" (LÉON-DUFOUR, 1984, p. 24). A Igreja, concretamente a 
comunidade cristã em assembleia litúrgica, é o sujeito integral de toda ação litúrgica (CONGAR, 1969).

De fato, escrevendo aos Coríntios, Paulo dirige-se à comunidade toda. Não só no cabeçalho (1Cor 1,1-2), mas, especificamente, quando fala da eucaristia, onde abundam os pronomes “nós" (1Cor 10,14-22) e "vós", "vos", "vossos", "vossas" (1Cor 11,17-34), referidos aos "bem-amados" reunidos "em Igreja" (1Cor 11,18).

Muito bem: quem faz [celebra] a eucaristia é a comunidade congregada para tal fim. Se é a comunidade, quer isso dizer que todos fazem tudo e tudo da mesma maneira? Há alguém que preside a celebração da eucaristia nas comunidades paulinas? Há algum presidente fixo, ou a presidência passa de mão em mão, num sistema de rodízio? A presidência da eucaristia obedece a algum princípio institucional ou é entregue àquele que, na ocasião, manifestar habilidade para tanto? Afinal, o que dizem os escritos paulinos a respeito? E o restante do Novo Testamento?

Em Paulo, não se encontra nenhuma palavra sobre a presidência da ceia do Senhor. De 1 Cor 11 se deduz que, naquela Igreja, se celebrava a ceia do Senhor também estando Paulo ausente, mas não se diz se havia um ofício de presidência e quem o exercesse.

O mesmo pode-se dizer do restante do Novo Testamento: "Sobre a presidência da ceia do Senhor, o Novo Testamento não é explícito, ainda que as narrações sinóticas sublinhem que, na última ceia, Jesus estava "com os Doze” (Mt 26,20; Mc 14,17; cf. Lc 22,14: “com os apóstolos”) e, portanto, só eles receberam o mandamento: “Fazei isto em memória de mim” (Lc 22,19; 1Cor 11,24.25)" (CATTANEO, 1997, p. 205). Neste sentido, há a convicção de que, estando presente um apóstolo, caberia a ele a presidência, o que a celebração da fração do pão em Trôade confirmaria (At 20,7.11).

O formato da ceia familiar judaica festiva - sobre o qual se calcou a fração do pão cristã - parece decisivo para elucidar esta questão (LÉONDUFOUR, 1984, p. 28-30; MAZZA, 1996; MAZZA, 2005). Nestas ceias rituais, cabia ao chefe da casa (ou a um hóspede ilustre) a presidência. Comentando 1Cor 14,16 ("Se deres graças apenas com teu espírito, como poderá o ouvinte não iniciado dizer 'Amém' à tua ação de graças, visto que não sabe o que dizes?”), observa Ch. Perrot: “Ainda que a celebração da “ceia do Senhor” seja 
comunitária, parece haver uma distinção entre "todos" e "algum" (ou "alguns"): "Note-se, neste caso, a distinção feita, segundo os modos judaicos, entre os que recitam as orações "eucarísticas" e os que as convalidam" mediante o "amém" (PERROT, 2005, p. 77).

\section{2. "Quem preside a comunidade preside a eucaristia"}

Pode-se fundadamente dizer que, também na Igreja primitiva, quem presidia a Igreja local presidia a eucaristia (LEGRAND, 1977; GOMES, 1977; BANKS, 1999, p. 230).

Na Igreja de Antioquia da Síria - fundada por judeu-cristãos dispersos pela perseguição quando do martírio de Estêvão (cf. At 8,1-3; 11,19.26) segundo o testemunho de Inácio (primeiros lustros do século II), há um bispo, um presbitério e alguns diáconos, cabendo ao bispo, rodeado pelos presbíteros e diáconos, presidir a eucaristia (Efe 20,2), que deve ser única (Fil 4,1) e não pode ser celebrada sem o bispo: "Por legítima seja tida tão-somente a eucaristia feita sob a presidência do bispo ou por delegado seu" (Esm 8,1).

Justino, na I Apologia 67,3-8 (aproximadamente 150-160 d.C.), informa que a presidência da eucaristia compete ao proestós ton adelphôn (aquele que é preposto aos irmãos), o qual — depois da leitura das memórias dos apóstolos e dos escritos dos profetas (por um leitor), e da homilia (feita também pelo presidente), trazidos o pão, o vinho e a água - "eleva súplicas e ações de graças com toda a sua capacidade". Tertuliano (160-225 d.C.), no De corona militis n. 3, igualmente informa que "o sacramento da eucaristia nós o recebemos da mão de nenhum outro senão daqueles que presidem (praesidentium)".

Esta, aliás, foi a regra geral nos primeiros séculos: quem preside a Igreja local preside a sua eucaristia (LEGRAND, 1977). Não no sentido em que ele celebra, e os demais assistem passivamente. Mas no sentido em que todos são solidariamente responsáveis pela comunidade local, ainda que não da mesma forma e ao mesmo título; no sentido em que os ministros são, por um lado, "iguais" aos demais cristãos e cristãs, mas, por outro, "diferentes" deles porquanto não só estão na Igreja, mas são seus presidentes, guias, pastores; o "nós" que o presidente da eucaristia frequentemente usa não é um plural 
majestático, mas o "nós" que é a assembleia da qual ele faz parte, que ele representa e à qual preside em nome de Cristo: "As orações dirigidas a Deus pelo sacerdote que preside, em representação de Cristo, à assembleia, são ditas em nome de todo o povo santo [nomine totius plebis sanctae] e de todos os que estão presentes [et omnium circunstantium]" (SC 33).

A eucaristia, de fato, era celebrada por toda a assembleia, estruturada ministerialmente, sob a presidência do bispo ou - a partir do surgimento das paróquias, no século IV - também de um presbítero. Esta foi a prática e a consciência compartilhadas no período patrístico e, de modo geral, em toda a Alta Idade Média (da metade do século $V$ à metade do século $X$, aproximadamente). Alguns perigos, porém, rondam esta prática.

A reviravolta pela qual passou a compreensão da eucaristia entre os séculos IX e XI, entretanto, repercutiu também na celebração da eucaristia. Aquelas inovações na compreensão da eucaristia vieram acompanhadas por uma crescente separação entre o clero e os demais fiéis. É bom lembrar, porém, que, já por volta do século III, dera-se aquilo que Alexandre Faivre chama de ereção de uma "barreira institucional" (FAIVRE, 1986, p. 61 e 93) entre clero e leigos, acentuando-se, por um lado, a distinção entre ministros ordenados e leigos, o que redundou num crescente distanciamento entre sacerdotes e leigos e, a fortiori, leigas, na celebração da eucaristia; por outro, assiste-se a uma sacralização (e até mesmo divinização) dos ministros ordenados, particularmente do bispo, o que, a médio e longo prazo, levou a um esvaziamento teológico e prático dos leigos. O que Tertuliano definiu no início do III século (leigo = non clericus) deu um de seus amargos frutos no século IX.

Comenta J.-A. Jungmann:

A separação entre o altar e o povo, entre os clérigos e os leigos, entre os portadores da plenitude do sacerdócio e a comunidade - esta separação, que pertence à essência mesma da Igreja, nunca foi esquecida - tende a tornar-se cada vez mais evidente, e pode-se falar mesmo de uma barreira entre os dois (JUNGMANN, 1950, p. 116).

Expressam com toda a clareza esta barreira: a manutenção do latim na liturgia, apesar de ser compreendido apenas por uma parte do clero e da aristocracia; a colocação do altar contra a parede, ao fundo da ábside; a criação de sacrários, normas e práticas de piedade voltados para a conservação e a 
veneração das hóstias consagradas no interior das igrejas; o deslocamento da cátedra episcopal para o lado direito da ábside; a tribuna vai se transformando num verdadeiro muro de separação entre o coro reservado aos sacerdotes e a nave da igreja.

Esta divisão, este muro, entre clérigos e povo no culto público da Igreja — "a chaga da mão esquerda da santa Igreja", segundo Rosmini (1968, p. 3955) - perdurou oficialmente até a segunda metade do século XX!

\subsection{Em comunhão com a Igreja local na comunhão universal das Igrejas}

Graças, porém, a um conjunto de ideias e movimentos - no nosso caso, sobretudo o movimento litúrgico - que convergiram no Concílio Vaticano II, a presidência da eucaristia só pode ser vista na Igreja e a serviço da Igreja, concretamente, a assembleia dos fiéis (plebs, coetus), que é o verdadeiro sujeito da ação litúrgica. É suficiente a afirmação de Sacrosanctum Concilium 26 (SC): "As ações litúrgicas não são ações privadas, mas celebrações da Igreja, que é o "sacramento da unidade", isto é, o povo santo, unido e ordenado sob a direção dos bispos". Convém lembrar que o próprio Concílio de Trento, no Decreto sobre a Missa, ensina:

Celebrada, de fato, a Páscoa, que a multidão dos filhos de Israel imolava em recordação da saída do Egito (cf. Ex 12), [Jesus] instituiu a nova Páscoa, isto é, a si mesmo, que devia ser imolado pela Igreja por meio dos seus sacerdotes sob sinais visíveis, em memória da sua passagem deste mundo ao Pai, quando nos redimiu com a efusão do seu sangue, nos "libertou do poder das trevas e transferiu no seu reino" $(\mathrm{Cl} 1,13)(\mathrm{DH} 1741)$.

Por isso [continua Sacrosanctum Concilium] estas celebrações pertencem a todo o Corpo da Igreja, e o manifestam e afetam; mas tocam (attingunt) a cada um dos membros de modo diferente, conforme a diversidade de ordens, ofícios e da participação atual (SC 26).

Não se pode captar o verdadeiro alcance desta afirmação (de per si muito tradicional) se não levando em conta o contributo que veio progressivamente do Movimento litúrgico, no interior do qual diversos autores procuraram recuperar a dimensão eclesial do culto, não só como 
afirmação de princípio, mas também como exigência de envolvimento de todos os fiéis na ação litúrgica. Tratava-se de reaproximar ativamente os fiéis daquela liturgia que, ao longo dos séculos, se tornara geralmente prerrogativa dos ministros sacros ou dos monges, substituída com orações de tipo devocional (GIRARDI, 2014, p. 140).

Daí decorrem: a preferência pela celebração comunitária (SC 27); 0 princípio segundo o qual, "nas celebrações litúrgicas, cada qual, ministro ou fiel, no desempenho de sua função, faça tudo e só aquilo que pela natureza da coisa ou pelas normas litúrgicas lhe compete" (SC 28); o reconhecimento de que os que servem ao altar, os leitores, comentadores e elementos do grupo coral exercem um autêntico ministério litúrgico (SC 29); a promoção das expressões típicas da participação ativa dos fiéis - aclamações, respostas, salmodia, antífonas, cânticos, bem como ações, gestos e atitudes corporais (SC 30) - inclusive prevendo-as nas rubricas dos novos livros litúrgicos (SC 31); a desautorização de qualquer acepção de pessoas na liturgia (SC 32); o uso do vernáculo (SC 36), etc.

Evidentemente, para encontrar sua plena legitimação teológica, o princípio enunciado em Sacrosanctum Concilium 26 tinha que se articular, como a seu contexto natural, com o conjunto da renovação da eclesiologia. Com efeito, não basta dizer que a liturgia é celebração da Igreja; é necessário especificar que a Igreja é uma realidade unitária - mistério de comunhão, povo de Deus, sacramento - e que todos os membros compartilham o seu ser, a sua edificação, a sua missão. Em outras palavras: são sujeitos! Neste sentido, SC 26 deve ser lido no horizonte de SC 14 (preâmbulo à parte relativa à “necessidade de promover a educação litúrgica e à ativa participação”): o direito-dever dos fiéis de participar na liturgia tem seu fundamento no batismo, portanto, na condição cristã comum a todos os membros do povo de Deus. Comenta Congar:

Está aí o fundamento da reforma litúrgica, que visa, de um lado, a restituir sua verdade às celebrações e, do outro lado, a promover a participação dos fiéis. São eles, é a ecclesia, ela mesma compreendida, na linha dos Padres, como o 'nós' dos cristãos" (CONGAR, 1967, p. 88; GRILLO, 2012).

A Lumen gentium (LG), por sua vez, desenvolverá particularmente uma visão de Igreja como povo de Deus, segundo a qual 
Ainda que alguns por vontade de Cristo sejam constituídos mestres, dispensadores dos mistérios e pastores em benefício dos demais, reina, contudo, entre todos verdadeira igualdade quanto à dignidade e ação comum a todos os fiéis na edificação do Corpo de Cristo. Porquanto a distinção que o Senhor estabeleceu entre os ministros sacros e o restante do Povo de Deus traz entre si uma verdadeira união (LG 32).

Neste contexto, ganha toda sua relevância os n. 10 e 11 da mesma Lumen gentium sobre o sacerdócio comum e sua expressão nos sacramentos, respectivamente.

A liturgia, portanto - especialmente a celebração da eucaristia pertence a todo o corpo da Igreja, o manifesta e o implica (SC 2). Contudo,

não se deve temer que isto signifique uma anulação das distinções ministeriais. De fato, cada membro da comunidade participa da mesma ação litúrgica segundo a própria condição e eventual função ministerial. A unidade orgânica da comunidade que celebra contém as diferenças dos ministérios, impedindo que cada um pretenda esgotar em si a realidade da Igreja a ponto de desautorizar os outros na realização das ações litúrgicas (GIRARDI, 2014, p. 141).

Tratando-se de todo o corpo da Igreja, o ministério pastoral — que, a seu modo e no que lhe cabe, sucede o ministério dos apóstolos - tem que estar necessariamente presente. A eucaristia só pode ser presidida por um bispo ou por um presbítero; sem a presidência de um bispo ou de um presbítero não existe eucaristia. A Lumen gentium, falando do múnus episcopal de santificar, afirma: "O bispo, distinguido pela plenitude do sacramento da Ordem, é o "administrador da graça do sacerdócio supremo", mormente na eucaristia, que ele mesmo oferece ou cuida que seja oferecida, e pela qual a Igreja vive e cresce" (LG 26a). Mais adiante, falando dos presbíteros, este documento ainda diz:

Cristo, a quem o Pai santificou e enviou ao mundo (Jo 10,36), fez os bispos participantes de Sua consagração e missão, através dos Apóstolos, de quem são sucessores. Os bispos passaram legitimamente o múnus do seu ministério, em grau diverso, a pessoas diversas na Igreja. Assim, o ministério eclesiástico, divinamente instituído, é exercido em diversas ordens pelos que desde a antiguidade são chamados bispos, presbíteros e diáconos. Embora os presbíteros não possuam o ápice do pontificado e no exercício de seu poder dependam dos bispos, estão, contudo, com eles unidos na dignidade sacerdotal (LG 28). 
Os diáconos, contudo, como ensina Lumen gentium 29, recebem a imposição das mãos “não para o sacerdócio, mas para o ministério”. Sabe-se, entretanto, que o texto está truncado. No original, se lê: "Na ordenação do diácono, só o bispo impõe as mãos porque o diácono não é ordenado para o sacerdócio, mas para o serviço do bispo: para fazer o que lhe é por este determinado" (TRADIÇÃO APOSTÓLICA 23, 15-20). Nos Statuta Ecclesiae Antiqua (Gália, em torno do ano 475), falta a parte final: “Quando é ordenado um diácono, só o bispo, que o abençoa, imponha a mão sobre a sua cabeça, pois é consagrado não para o sacerdócio (non ad sacerdotium), mas para o ministério (sed ad ministerium)".

Numa palavra, a Igreja que faz a eucaristia é a Igreja toda, reunida em assembleia eucarística, presidida por um bispo ou um presbítero, como ensina aquela pérola de eclesiologia eucarística de Lumen gentium 26:

\begin{abstract}
Esta Igreja de Cristo está verdadeiramente presente em todas as legítimas comunidades locais de fiéis, que, unidas com seus pastores, são também elas no Novo Testamento chamadas "igrejas". Estas são em seu lugar o povo novo chamado por Deus, no Espírito santo e em grande plenitude (1Ts 1,5). Nelas se celebra o mistério da Ceia do Senhor "a fim de que, comendo e bebendo o corpo e o sangue do Senhor, toda a fraternidade se uma intimamente" [Oração moçárabe: PL 96, 759B] Em toda comunidade de altar unida para o sacrifício, sob o ministério sagrado do bispo, manifesta-se o símbolo daquela caridade e "unidade do corpo místico, sem a qual não pode haver salvação" [S. Tomás de Aquino, Summa theologiae III, q. 73, a.3]. Nestas comunidades, embora pequenas e pobres, ou vivendo na dispersão, está presente Cristo, por cuja virtude se consocia a Igreja una, santa, católica e apostólica. Pois "a participação do corpo e do sangue de Cristo não faz outra coisa senão transformar-nos naquilo que tomamos" [São Leão Magno, Sermo 63,7: PL 54, 357C].
\end{abstract}

O Documento Preparatório do Sínodo para a Amazônia tem plena consciência da complexidade da questão. Aliás, quando toca no assunto das comunidades sem acesso à celebração frequente da eucaristia, vai distinguindo os vários níveis da questão:

\footnotetext{
A Assembleia Especial para a Região Pan-Amazônica precisa de um grande exercício de escuta recíproca, que se faça especialmente entre o Povo fiel e as autoridades do magistério da Igreja. E um dos pontos principais a ser escutado será o lamento «de milhares dessas comunidades desprovidas (carentes) da eucaristia dominical por longos períodos (cf. DAp 100e) (SECRETARIA GERAL DO SÍNODO: Documento Preparatório n. 64).
} 
Mais adiante, o Documento Preparatório pondera: "Nesse sentido, o Vaticano II nos lembra que todo o povo de Deus participa do sacerdócio de Cristo, embora distinguindo sacerdócio comum do sacerdócio ministerial (cf. LG 10). (DOCUMENTO PREPARATÓRIO, n. 81). Partindo daí, urge avaliar e repensar os ministérios que hoje são necessários para responder aos objetivos de uma Igreja com rosto amazônico e indígena.

\begin{abstract}
Uma prioridade é [...] definir os conteúdos, métodos e atitudes para se constituir uma pastoral inculturada, capaz de responder aos grandes desafios no território. Outra é [...] propor novos ministérios e serviços para os diferentes agentes de pastoral que respondem pelas tarefas e responsabilidades da comunidade. Nessa perspectiva, é preciso identificar o tipo de ministério oficial que pode ser conferido à mulher, levando em conta o papel central que hoje desempenham as mulheres na Igreja amazônica. Também é necessário [...] promover o clero indígena e os que nasceram no território, afirmando sua própria identidade cultural e seus valores. Finalmente, é preciso repensar novos caminhos para que o Povo de Deus tenha melhor e frequente acesso à eucaristia, centro da vida cristã (cf. DAp 251). (SECRETARIA GERAL DO SÍNODO: Documento Preparatório n. 81).
\end{abstract}

E, após as reflexões feitas no corpo do documento, vem uma série de questões para facilitar a escuta das realidades da região amazônica. Entre elas: "A seu ver, quais são os serviços e os ministérios com rosto amazônico que deveriam ser criados e promovidos?" (SECRETARIA GERAL DO SÍNODO: Documento Preparatório Parte III, n.10).

\title{
2. Em busca de uma resposta para a situação amazônica
}

Não vamos abordar aqui o perfil concreto que, a nosso ver, deveria ter o futuro presidente de comunidade, que, devidamente ordenado presbítero, por presidir a comunidade, poderá e deverá também presidir a celebração da eucaristia da comunidade. Chamamos a atenção apenas para alguns pontos que nos parecem básicos na busca de saídas para a situação ministerial na região amazônica: a) muitas comunidades têm homens aptos à ordenação presbiteral; b) perfil moral e social dos eventuais candidatos à ordenação; c) a "graça" do ministério é maior que a "lei" do celibato; d) a reflexão sobre a ordenação sacerdotal de mulheres deve continuar; e) o santo povo fiel de Deus precisa ser ouvido; f) os padres atuais têm um significado e um papel importantes; g) a responsabilidade dos bispos nas dioceses e no Sínodo. 


\subsection{Muitas comunidades têm homens aptos à ordenação presbiteral}

Em muitas comunidades, homens e mulheres, às vezes jovens, mas de modo geral adultos, assumem os mais diversos serviços e ministérios. São animadores de Grupos de Jovens, responsáveis pela Promoção Humana, líderes da Pastoral da Criança, pessoas dedicadas à Pastoral da Saúde, coordenadores de Círculos Bíblicos (em alguns lugares, Grupos de Reflexão ou Grupos de Vivência), missionários, visitadores, promotores do Dízimo, responsáveis pela Economia e Finanças da comunidade, catequistas, equipes de celebração (comentaristas, leitores, salmistas, cantores, acólitos, instrumentistas, presidentes) e serviço de Liturgia, presidentes de Celebrações da Palavra, animadores de Comunidades — sejam Comunidades Eclesiais de Base, sejam Setores ou Comunidades semelhantes dentro da paróquia ou referidas diretamente à Diocese (ALMEIDA, 1989; ALMEIDA, 2013).

Nessas comunidades, o Espírito tem sido generoso: "a cada um é dado um dom do Espírito para utilidade comum" (1Cor 12,7). Mesmo assim, elas não têm um presbítero próprio e permanente para presidi-las e, consequentemente, para presidir a celebração da eucaristia.

Será que ninguém, nessas comunidades, teria vocação para assumir o ministério presbiteral? Será que o Espírito Santo, que, na Igreja de Corinto, distribuiu entre seus membros os dons mais variados, de modo que ela tivesse tudo o que lhe era necessário para ser Igreja e para realizar a missão (cf. 1Cor 12,4-11.28-30) - inclusive a celebração da eucaristia (cf. 1Cor 11) - nos dias atuais, não está agindo da mesma maneira? Estaria o Espírito dando alguns dons, mas não todos? Por que dá dons que nem seriam tão necessários, e deixaria de dar outros que são essenciais para a comunidade ser plenamente Igreja? Por que, nos últimos tempos, as vocações para o presbiterado só aumentam em alguns países da África e em parte da Ásia? "A direita do Altíssimo mudou" (SI 77,11)?

O problema não está, evidentemente, do lado de Deus, mas do nosso, que, em relação a esta questão da falta — em muitos lugares, crônica; em algumas áreas, relativa; em outras, absoluta — de ministros ordenados para a presidência da eucaristia nas comunidades, não temos sido capazes como 
Igreja de ver e interpretar os "sinais dos tempos" (Gaudium et spes 4) e de ir ao essencial em matéria de ministério presbiteral, voltando à praxe da Igreja nascente, da Igreja antiga e muito além: “Nenhuma comunidade sem eucaristia, nenhuma eucaristia sem comunidade. Nenhuma comunidade sem seu ministro ordenado, nenhum ministro ordenado sem sua comunidade"! De fato,

a comunidade não precisava ser grande para ter um bispo e um grupo de presbíteros - um presbitério - à sua frente. Ela precisava ser consciente e dinamicamente cristã... Uma comunidade com um mínimo de doze famílias podia, no século Il, ter um bispo! (LOBINGER \& ALMEIDA, 2009, p. 9; FLICHE \& MARTIN, 1946, p. 375).

Liberada de condicionantes ao acesso ao ministério presbiteral que, sob certos aspectos e em determinados contextos, podem ser considerados convenientes, mas jamais em si necessários e universalmente exigíveis, a Igreja se colocaria em melhores condições para selecionar bons candidatos - entre jovens e adultos, solteiros e casados, com formação universitária e sem - ao ministério presbiteral.

O bispo emérito de Aliwal, na África do Sul, Fritz Lobinger, não sugere meramente a ordenação de "viri probati", mas a ordenação de homens, casados ou solteiros, em comunidades que tenham uma boa caminhada eclesial-comunitária, dotadas de serviços e ministérios não-ordenados nos vários âmbitos da vida e da missão da Igreja (palavra - culto - caridade), cujos membros e lideranças estejam tendo acompanhamento e formação adequada às suas necessidades pessoais, familiares, pastorais e missionárias: communitates probatae! Caberia à própria comunidade, integrada, evidentemente, na Igreja local, com seu presbitério e seu bispo diocesano, a escolha daqueles que, uma vez ordenados para o presbiterado, presidiriam a comunidade e, consequentemente, a eucaristia da comunidade.

Não temos dúvida de que, também na região amazônica, há comunidades maduras (communitates probatae) e há homens maduros (viri probati) em condição de ser chamados e ordenados para assumirem o ministério presbiteral nestas mesmas comunidades. 


\subsection{Que homens são estes aos quais se poderia impor as mãos?}

São, em sua imensa maioria, pessoas muito parecidas com aqueles discípulos que Jesus chamou para segui-lo em seu ministério chamado público: camponeses, pescadores, moradores de pequenas cidades, algum comerciante, um funcionário público. Jesus tem muito em comum com eles: filho de uma mulher simples do povo, casada com um artesão/carpinteiro. Não só trabalhou, mas conheceu e conviveu com trabalhadores. As suas palavras são tiradas da vida familiar, do trabalho agrícola ou de fatos mais ou menos corriqueiros da vida quotidiana: a mulher que perde uma moeda, o filho que deixa a casa do pai, as invejas e ciúmes entre irmãos, o lavrador que lança a semente à terra, o vinicultor que poda o parreiral no tempo certo, as frutíferas estéreis, a lida paciente e difícil dos pescadores. Aliás, a maioria dos seus discípulos galileus eram pescadores. Entre os missionários cristãos e as lideranças das pequenas comunidades que vão pipocando nas cidades onde $o$ evangelho de Jesus é anunciado, há, sim, gente com maior autonomia social e pessoas com maior qualificação intelectual - pense-se em Paulo, Barnabé, Apolo ou Silas - mas os mais são gente simples. Muitos certamente eram mesmo analfabetos, pois a taxa de alfabetização naquela área na época era muito baixa, em torno de 10\%. O próprio Paulo trabalhava como artesão, junto com Priscila e Áquila (At 18,3), para não pesar à comunidade, que, em Corinto, por exemplo, geralmente não tinha "muitos sábios segundo a carne, nem muitos poderosos, nem muitos de família prestigiosa" (1Cor 1,26). Os líderes locais que não pudessem viver de seu próprio trabalho eram mantidos por suas comunidades (1Tm 5,17-18). Embora Paulo fosse celibatário (1Cor), os líderes locais - entre os judeu-cristãos, chamados "presbíteros"; entre os helenistas, chamados "epíscopos" - tinham família, esposa e filhos; o que, porém, não Ihes podia faltar eram outras qualificações: ser irrepreensíveis, temperantes, sóbrios, modestos, hospitaleiros, aptos para ensinar; não dados ao vinho, não violentos, cordatos, inimigos de contendas, não avarentos; capazes de governar bem a própria casa; não neófitos; gozarem do bom testemunho dos de fora (cf. 1Tm 3,2-7).

Uma figura semelhante a esta é que imaginamos para os futuros "padres de comunidade": exemplos do "bom-viver" (vida simples, sem vícios, 
senhores de si, humildes); bons cristãos; fortes da caminhada comunitária; bons maridos e pais; sábios pela graça de Deus e pela experiência de vida; benquistos pelos de dentro; respeitados pelos de fora; generosos com todos, especialmente os pobres. Formados na comunidade e na ação, sabem que não sabem e, por isso, buscam aperfeiçoar-se a cada dia em todas as dimensões da vida, para servir melhor.

\subsection{A "graça" do ministério é maior que a "lei" do celibato}

Poderá haver "padres de comunidade" solteiros ou celibatários, mas esta não é uma regra. Em relação ao celibato, portanto, será preciso distinguir, com toda a clareza, o carisma do celibato (que é um dom e uma opção pessoal) (cf. 1Cor 7,1-9, especialmente o v. 7) e a lei do celibato (cf. Presbyterorum ordinis [PO] 16):

O nexo obrigatório, estabelecido pela Igreja latina, entre celibato e ordenação ao presbiterado e ao episcopado não se funda na Escritura. As prescrições das Cartas pastorais, as únicas do Novo Testamento relativas às eleições dos diáconos, presbíteros e bispos, supõem claramente que os futuros ordenados são homens casados, dos quais se exige uma vida familiar irrepreensível (1 Tim 3; Tt 1,5-9). Este nexo também não deriva da natureza do ministério ordenado, mas de uma decisão eclesial (LEGRAND, 1985, p. 241).

O carisma do celibato não está em discussão; o que pode ser discutido é a lei do celibato. Diz lapidarmente Paulo Suess: "O celibato é um dom, não um dogma" (2019, p. 391). Trata-se de uma questão disciplinar, não teológica, que foi gradativamente introduzida na Igreja latina, atingindo seu cume nos cânones 6 e 7 do II Concílio do Latrão (1139). Mesmo assim, ainda que a conveniência do celibato para os ministérios ordenados seja múltipla (cf. PAULO VI, SacCoel 18), aspectos desta conveniência, em determinadas circunstâncias, podem ser razoavelmente questionados. Paulo VI tinha clara consciência dos questionamentos atuais ao ponderar (e, em seguida, descartar) as objeções ao celibato e à lei do celibato: vocação ao ministério e vocação ao celibato são vocações distintas; o drama da preocupante escassez de clero; as sombras sobre a vivência do celibato; o conflito entre o celibato e o instinto sexual; a formação inadequada dos futuros padres para a vida celibatária, etc. (SacCoel, 5-11). O que não dá para entender - desculpem a expressão - é que uma ou algumas disposições disciplinares não intrínsecas 
ao ministério sacerdotal se sobreponham ao direito-dever de uma comunidade de usufruir da celebração da eucaristia, num evidente conflito entre o "direito de legislação” e o “direito da graça” (DOMBOIS, 1961; 1974-1983; HOFFMANN, 1968). Não estamos falando do direito "à" graça, mas do direito “da” graça, maior que o direito da lei! Comenta Legrand:

A comparação entre a disciplina do Oriente e do Ocidente católicos mostra que a ordenação ao presbiterado é compatível com diferentes estados de vida (assim Presbyterorum ordinis faz o elogio dos padres casados), porque o celibato não se enquadra no direito sacramental nem no direito institucional no sentido em que foi definido, mas no direito de legislação como o próprio decreto conciliar igualmente o diz (PO 16). Uma delicada questão de ajustamento entre estes dois direitos seria colocada se prescrições relativas ao estado de vida dos padres (enquadradas, portanto, no direito de legislação) viesse a comprometer o direito sacramental. Estarse-ia diante de uma situação deste gênero, parece-nos, se a deficiência do número de cristãos capazes de viver o celibato, desde que estando aptos à ordenação, viesse a privar a Igreja deste ou daquele país dos padres necessários aos quais os cristãos têm direito, sem que a solidariedade de outras Igrejas locais pudesse remediar os graves danos que daí resultariam para a vida cristã. Repetimo-lo: não se trata de colocar em causa a necessidade e os méritos de um direito de legislação, mas convém que seja sempre regulado pelo direito da graça. Quando se abstém deste discernimento e o direito de legislação toma um lugar dominante, então racionalismo abstrato e legalismo arriscam de prevalecer sobre a graça do Evangelho e sobre a sua liberdade (LEGRAND, 1979, p. 166; HOFFMANN, 1968).

Para honrar o "direito da graça”, a Igreja não só pode, mas deve — pois o “direito da legislação" está prejudicando a vida cristã de milhares de comunidades - para o Ocidente, seja acolher a praxe oriental em que se convivem um clero celibatário e um clero casado (cf. PO 16; SC 15; OE 5), seja abrir exceções, como já ocorre em alguns casos, ou conceder dispensas mais abrangentes da lei geral. Em algumas entrevistas (por exemplo, ao jornal Die Zeit em 2017, na viagem de volta da Jornada Mundial da Juventude de 2019), o Papa Francisco já se mostrou aberto a analisar essas alternativas.

\subsection{O santo povo fiel de Deus precisa ser ouvido}

Em relação à região amazônica, é preciso encontrar — e sem mais delonga, pois a demora já leva quatro séculos - alguma solução para a situação das milhares de comunidades sem celebração regular da eucaristia, e esta solução precisa ser buscada por todos. É necessário refletir sobre "a 
estreita relação entre Igreja e Eucaristia, porque sem a Eucaristia não há Igreja, e não pode se condenar perpetuamente sem Eucaristia as inúmeras comunidades dispersas e remotas" (CODINA, 2019). O povo católico da Amazônia sofre na própria pele a falta de pastores próprios que vivam nas comunidades e convivam com o povo. Esta situação não pode perdurar indefinidamente. É um escândalo eclesial, um absurdo eclesiológico!

O sábio adágio antigo continua atual, não por ser antigo, mas por ser sábio: Quod omnes tangit ab omnibus tractari debet (o que afeta a todos deve ser tratado por todos). Não só por ser sábio, mas por se fundamentar, em âmbito eclesial, no sensus fidei fidelium do povo de Deus, como bem lembrou o Concílio Vaticano II: "o conjunto dos fiéis, ungidos que são pela unção do Santo (cf. 1Jo 2,20.27), não pode enganar-se no ato de fé. E manifesta esta sua peculiar propriedade mediante o senso sobrenatural da fé de todo o povo quando, "desde os bispos até os últimos fiéis leigos", apresenta um consenso universal sobre questões de fé e costumes" (LG 12).

Não se trata, portanto, de uma reivindicação de democracia na Igreja nem de pautar as decisões eclesiais pelo critério da maioria. (Ainda que a Igreja possa aprender muito com a democracia). O que está em jogo é muito mais que isso; é honrar a condição cristã comum a todos os membros da Igreja, dada pelo batismo, que confere a todos os fiéis uma dignidade única, uma habilitação à participação na missão sacerdotal, régia e profética de Cristo, e no sentido sobrenatural da fé de todo o povo de Deus.

A consciência deste estatuto ontológico do povo cristão se exprimiu, nos primeiros anos do cristianismo, entre outras coisas, numa participação ativa das comunidades em decisões importantes, como a eleição de Matias para ocupar a vaga deixada por Judas (At 1,15-26), a decisão de dotar a parte helenista da Igreja de Jerusalém de uma estrutura ministerial própria ("os Sete": At 6,1-6), o envio de alguns profetas e doutores da Igreja de Antioquia para a evangelização dos gentios (At 13,1-3) e a controvérsia sobre a circuncisão dos gentios (At 15).

Nos dias atuais, em que se ressaltam o sensus fidei e o sensus fidelium (COMISSÃO TEOLÓGICA INTERNACIONAL, 2014) e em que o Papa Francisco insiste na prática da sinodalidade, acreditamos que a questão da ordenação presbiteral de líderes de comunidades, casados ou solteiros, deva ser debatida 
por todos os fiéis, especialmente pelas comunidades que vivem uma situação de escassez relativa ou absoluta de presbíteros.

O Papa Francisco, na Constituição apostólica Episcopalis communio (EC) sobre o sínodo dos bispos, lembra que o bispo é ao mesmo tempo mestre e discípulo:

Ele é mestre quando, dotado de uma especial assistência do Espírito Santo, anuncia aos fiéis a Palavra de verdade em nome de Cristo cabeça e pastor. Mas ele é também discípulo quando, sabendo que o Espírito é dado a todo batizado, se põe à escuta da voz de Cristo que fala através de todo o Povo de Deus (...) Um bispo que vive em meio aos seus fiéis tem os ouvidos abertos para escutar "aquilo que o Espírito diz às ovelhas" (Ap 2,7) e para escutar a "voz das ovelhas" (FRANCISCO, Episcopalis communio 5)

O Sínodo dos Bispos, segundo o Papa, deve tornar-se sempre mais um instrumento privilegiado de escuta do Povo de Deus: "Para os Padres sinodais, pedimos, do Espírito Santo, antes de mais nada o dom da escuta: escuta de Deus, até ouvir com Ele o grito do povo; escuta do povo, até respirar nele a vontade de Deus que nos chama" (Episcopalis communio 6).

Se um elemento constitutivo da sinodalidade é a escuta, a hierarquia é convocada a ouvir (cf. Episcopalis communio 5), sobretudo quando se trata de situações e questões vividas em primeira pessoa pelos fiéis leigos e leigas: família, casamento, vida conjugal, educação dos filhos, trabalho, vida profissional etc. A vida vivida da hierarquia e dos leigos e leigas é diferente, a ótica e o horizonte muito distintos, as preocupações estão longe de ser as mesmas, e tudo isso condiciona seja a abordagem seja os resultados. No caso que nos ocupa aqui, a falta de presbíteros e de celebração da eucaristia em muitas comunidades afeta de maneira muito diferente os bispos de uma conferência episcopal, o bispo local, o padre que só pode passar pela comunidade uma vez por ano, e os que insistem em ser católicos neste deserto pastoral e sacramental.

Temos que ouvir o povo, temos que aprender a ouvir o povo, temos que aprender com o povo, temos que elaborar com o povo as decisões pastorais (e outras), mesmo que, ao cabo, por direito, competir aos bispos e, entre eles, particularmente ao papa, tomar a decisão final. 
Nesta linha, na fase de consulta do Sínodo para a Amazônia, graças à insistência do Papa Francisco sobre a sinodalidade e ao trabalho da Rede Eclesial Pan-Amazônica (REPAM), dezenas de milhares de pessoas - na verdade, cerca de 87.000 - foram ouvidas em seus próprios contextos. Em relação à ordenação sacerdotal de homens casados, as opiniões favoráveis são recorrentes; pode-se falar tranquilamente de uma unanimidade não só moral, mas física.

\subsection{A reflexão sobre a ordenação sacerdotal de mulheres deve continuar}

Impressiona também o alto índice de postulações de ordenação de mulheres, não obstante a posição firme contrária do Magistério papal. A questão, porém, da ordenação de mulheres ao sacerdócio (entendendo-se episcopado e presbiterado) - não ao diaconato, que, segundo bem fundamentados estudos, que vão muito além da disputa entre Vagaggini (1974) e Martimort (1982), existiu na Igreja por séculos - é diferente da questão do celibato e mais complexa.

É um fato, porém, e não só no Brasil, que as mulheres assumem a maior parte dos serviços e ministérios nas paróquias e comunidades. É sabido também que a ordenação de mulheres é uma demanda que tem crescido, sobretudo em áreas culturalmente mais liberais, mas não só. O Papa Francisco tem viva consciência deste desafio: “As reivindicações dos legítimos direitos das mulheres, a partir da firme convicção de que homens e mulheres têm a mesma dignidade, colocam à Igreja questões profundas que a desafiam e não se podem elidir superficialmente" (EG 104).

O Papa Francisco, entretanto, assim como Paulo VI (Inter Insigniores, 1976) e João Paulo II (Ordinatio Sacerdotalis, 1994), tem declarado que esta porta está fechada. Portanto, na conjuntura atual, o sacerdócio continuará reservado a pessoas do sexo masculino; consequentemente, nenhum remédio à escassez de sacerdotes deve ser buscado na direção da eventualidade da ordenação das mulheres. Isto, contudo, não pode querer dizer que não se possam examinar os múltiplos argumentos alegados pelo magistério pontifício, especialmente o peso das opções hermenêuticas prévias que as 
fundamentam, seja em nível do estatuto da Tradição, seja em nível da argumentação bíblica, seja em nível teológico (BORRAS, 2017, p. 189-193).

A Gaudium et spes traz uma observação lúcida e corajosa sobre a relação entre fé e cultura: "Ainda que a Igreja muito tenha contribuído para o progresso da cultura, mostra, contudo, a experiência que, por razões contingentes, a harmonia entre a cultura e o cristianismo nem sempre se realiza sem dificuldades" (GS 62a) E, a seguir, faz uma indicação preciosa: "Estas dificuldades não são necessariamente danosas para a vida da fé; antes, podem levar o espírito a uma compreensão mais exata e mais profunda da mesma fé. Efetivamente, as recentes investigações e descobertas das ciências, da história e da filosofia, levantam novos problemas, que implicam consequências também para a vida e exigem dos teólogos novos estudos" (GS 62). A teologia, como sabemos e repetimos, não pode deixar de buscar respostas às questões que são levantadas pelos próprios fiéis ou por pessoasque querem entender ou mesmo questionam determinadas afirmações doutrinais.

Não é outra a convicção do Papa Francisco:

\begin{abstract}
A liberdade teológica é necessária. Sem a possibilidade de experimentar estradas novas, não se cria nada de novo, e não se deixe espaço à liberdade do Espírito do ressuscitado: A quantos sonham com uma doutrina monolítica defendida sem nuances por todos, isto poderá parecer uma dispersão imperfeita; mas a realidade é que tal variedade ajuda a manifestar e desenvolver melhor os diversos aspectos da riqueza inesgotável do Evangelho (cf. Evangelii gaudium 40). Isto significa também uma adequada revisão da ratio studiorum. Sobre a liberdade de reflexão teológica, eu faria uma distinção. Entre os estudiosos, é preciso ir adiante com liberdade; depois, em última instância, será o magistério a dizer algo, mas não se pode fazer uma teologia sem esta liberdade. Mas na pregação ao Povo de Deus, por favor, não ferir a fé do Povo de Deus com questões disputadas! As questões disputadas fiquem somente entre os teólogos. É a vossa tarefa. Mas ao Povo de Deus precisa dar a substância que aliemente a fé e que não a relativize (FRANCISCO, Discurso, 2019).
\end{abstract}

Ao longo da história, a Igreja viu-se às voltas, muitas vezes, com questões extremamente difíceis, em relação às quais emergiam, na comunidade eclesial, posicionamentos divergentes do consenso em vigor que, ao final, acabaram por invalidar o consenso anterior e criar um novo, de modo que "o que inicialmente era uma opinião divergente às vezes se tornou a doutrina mais comum e até mesmo oficial” (SULLIVAN, 1997). 


\subsection{Os padres atuais têm um significado e um papel inestimáveis}

Os padres atuais não precisam temer a chegada dos padres comunitários. Como não precisavam temer, cinquenta anos atrás, a restauração do diaconato! Ao contrário. Além de terem um significado peculiar graças à sua entrega total, têm uma importância e um papel decisivo nesta hora, no sentido de: a) intensificar o processo de implementação e consolidação de comunidades de dimensões humanas em suas áreas de atuação; b) fortalecer a presença de ministérios não-ordenados nas comunidades; c) dar prioridades à formação das pessoas e dos grupos ativos nas comunidades, especialmente animadores de comunidades e coordenadores de serviços e pastorais; d) aprofundar a reforma litúrgica promovida pelo Concílio, visando à participação ativa, consciente e frutuosa especialmente na eucaristia, de modo que a eucaristia seja, também experiencialmente, fonte e cume da vida cristã, da evangelização e da Igreja.

Se a Igreja abrir a porta para a ordenação presbiteral de líderes comunitários, solteiros ou casados, os padres atuais passarão a ter uma responsabilidade ainda maior, não só em relação à diocese toda, mas, particularmente, em relação ao acompanhamento, à animação, à formação dos padres de comunidade. Vem-me à mente aquela passagem de Atos, onde se lê que "os apóstolos [Paulo e Barnabé] designaram anciãos para cada Igreja e, com orações e jejuns, os confiavam ao Senhor, em quem tinham passado a crer" (At 14,23) e aquela outra em que Paulo diz a Barnabé: "Voltemos para visitar os irmãos em cada cidade onde anunciamos a palavra do Senhor, para ver como estão" (At 15,36), e ainda aquela em que Paulo, “percorrendo a Síria e a Cilícia, ia confirmando as igrejas" $(15,41)$. Mais do que hoje, talvez, as comunidades locais e seus ministros ordenados vão precisar que os padres atuais - em criativa itinerância - passem "para ver como estão" e para se sentirem "confirmadas" em sua nova caminhada. Isso não se choca com o Instrumento de Trabalho, quando diz: “As distâncias geográficas abrangem também distâncias culturais e pastorais que, portanto, exigem a passagem de uma "pastoral de visita" para uma "pastoral de presença", a fim de voltar a configurar a Igreja local em todas as suas expressões: ministérios, liturgia, 
sacramentos, teologia e serviços sociais" (Instrumentum laboris 128); ao contrário, coloca a itinerância (que é muito mais que a visita) a serviço da presença.

O celibato, que se justifica por razões cristológicas, eclesiológicas e escatológicas, como bem o mostrou Paulo VI na Sacerdotalis Coelibatus (cf. n. 17-34), “consente, além disso, ao sacerdote, mesmo no campo prático, como é evidente, a máxima eficiência e a melhor aptidão psicológica e afetiva para o exercício contínuo daquela caridade perfeita que lhe permitirá, de maneira mais ampla e concreta, dar-se todo para o bem de todos (cf. 2Cor 12,15), e garante-lhe, como é óbvio, maior liberdade e disponibilidade no ministério pastoral, na sua ativa e amorosa presença no mundo, ao qual Jesus Cristo o enviou (cf. Jo 17,18), a fim de que ele pague inteiramente a todos os filhos de Deus a dívida que tem para com eles (cf. Rm 1,14)" (Sac Coel 32). O presbítero celibatário goza de uma "liberdade e disponibilidade no ministério pastoral" que o presbítero casado não tem. A eventual introdução de presbíteros casados nos presbitérios diocesanos ensejaria uma virtuosa redefinição de papéis: os padres celibatários poderiam, por um lado, vir a se dedicar a serviços de nível diocesano e, por outro, a atividades de assistência, acompanhamento, formação, assessoria nos decanatos, paróquias e comunidades infradiocesanas.

\subsection{A responsabilidade dos bispos nas dioceses e no Sínodo}

Os bispos têm uma responsabilidade única neste processo, uma vez que depende principalmente deles uma participação ativa na discussão deste tema, no processo de preparar as decisões (decision-making) — e de tomada de decisão no caso dos Sinodais (decision-taking) — preparar suas Igrejas para uma eventual introdução de presbíteros casados, bem como coordenar o processo de sua implementação, respeitando, evidentemente, as orientações que vierem da Santa Sé e das Conferências episcopais, a partir do que for aprovado pelo Sínodo e, naturalmente, pelo papa.

O Instrumentum laboris reconhece que "as comunidades têm dificuldade para celebrar frequentemente a eucaristia devido à falta de sacerdotes" e propõe que se considerem dois possíveis encaminhamentos: 
$1^{\circ}$ ) "que... se mudem os critérios para selecionar e preparar os ministros autorizados para celebrá-la" (126, c); $2^{\circ}$ ) “que, para as zonas mais remotas da região, se estude a possibilidade da ordenação sacerdotal para pessoas anciãs [não pessoas idosas, que, no caso, seria uma tradução incorreta!] preferentemente indígenas, respeitadas e aceitas por sua comunidade, ainda que tenham já uma família constituída e estável[...]” (129, a, 2). Em relação ao primeiro ponto, o texto integral diz: "Por falta de sacerdotes, as comunidades têm dificuldade de celebrar com frequência a Eucaristia. "A Igreja vive da Eucaristia" e a Eucaristia edifica a Igreja. Por isso, pede-se que, em vez de deixar as comunidades sem a Eucaristia, se alterem os critérios para selecionar e preparar os ministros autorizados para celebrá-la" (IL 126, c). Quanto ao uso do termo "ancião(s)", há que se atentar que o significado do termo “ancião(s)" é dúplice e, obviamente, vai depender do contexto e da interpretação em que o sentido está sendo usado. Em princípio, se oposto a “jovem”, significa velho ou, comparativamente, mais velho de/que, maior de/que, um tanto velho, mais bem velho; mas pode ter um sentido mais amplo: vivido, experiente, maduro, sábio, respeitável; neste caso, o referencial não é a idade cronológica, mas a habilidade ou competência adquirida e reconhecida.

Os bispos, que são os sujeitos principais do Sínodo, certamente estão se preparando e chegarão lá com suas opiniões próprias, algumas consolidadas, outras claras, mas em aberto, algumas quase sem nenhum contorno. Certamente sabem da responsabilidade que cabe à totalidade do Povo de Deus e, especialmente a eles e aos teólogos e teólogas:

É dever de todo o Povo de Deus e, sobretudo, dos pastores e teólogos, com a ajuda do Espírito Santo, saber ouvir, discernir e interpretar as várias linguagens do nosso tempo, e julgá-las à luz da palavra de Deus, de modo que a verdade revelada possa ser cada vez mais intimamente percebida, melhor compreendida e apresentada de um modo conveniente (GS 43).

O Sínodo é um contexto de fala, mas também de escuta, sobretudo de escuta. O Sínodo dos Bispos deve tornar-se cada vez mais um instrumento privilegiado de escuta do Povo de Deus: «Para os Padres sinodais, pedimos, do Espírito Santo, antes de mais nada o dom da escuta: escuta de Deus, até ouvir com Ele o grito do povo; escuta do povo, até respirar nele a vontade de Deus que nos chama» (Episcopalis communio 6). 
Francisco cita expressamente João Paulo II:

Cada Assembleia Geral do Sínodo dos Bispos é uma forte experiência eclesial, embora possa ser sempre aperfeiçoada nas modalidades dos seus procedimentos. Os Bispos reunidos no Sínodo representam antes de mais nada as próprias Igrejas, mas têm em conta também as contribuições das Conferências Episcopais que os designaram fazendo-os portadores dos seus pareceres sobre as questões a tratar. Eles exprimem assim o voto do Corpo hierárquico da Igreja e, de algum modo, o do Povo cristão de quem são os Pastores (JOÃO PAULO II, PG 58).

O Sínodo, por conseguinte, não é um cenário de oposição de posições, mas de busca coletiva de sinergias e consensos em vista de um caminho comum. As sessões plenárias, os trabalhos em grupos, as conversas informais, tudo vai ampliando os horizontes dos participantes e propiciando decisões compartilhadas.

Em relação às questões a serem tratadas, o santo povo fiel de Deus espera, torce e reza para que seus bispos levem em séria consideração suas necessidades, seus problemas, seus questionamentos, suas opiniões sobre os temas em discussão, suas sugestões de encaminhamento em relação às questões que, para as comunidades eclesiais, especialmente neste momento as da Amazônia, não são meros problemas teóricos ou árduas questões doutrinais, mas sua vida concreta, seu dia a dia existencial, social e eclesial, suas alegrias e esperanças, tristezas e angústias (cf. GS 1). Embora seja um organismo essencialmente episcopal, o Sínodo não vive separado do resto dos fiéis. Pelo contrário, é um instrumento adequado para dar voz a todo o Povo de Deus precisamente por meio dos Bispos, constituídos por Deus «autênticos guardiões, intérpretes e testemunhas da fé de toda a Igreja», mostrando-se de Assembleia em Assembleia uma expressão eloquente da sinodalidade como «dimensão constitutiva da Igreja» (Episcopalis communio 6).

\section{Manter os ouvidos abertos para escutar "o que o Espírito diz às Igrejas"}

a. Não só o Papa Francisco, mas milhares de comunidades esperam uma resposta lúcida, corajosa e bem fundada para poderem celebrar com ministros próprios a eucaristia, "sinal da unidade" e "vínculo da caridade" (AGOSTINHO, In Johannis 26,13) da comunidade local e da comunhão universal. Estas 
comunidades não querem nenhum privilégio. Querem simplesmente resgatar, com as devidas atualizações institucionais e pastorais, a prática da Igreja primitiva e antiga: "Não havia Igreja sem eucaristia e não havia eucaristia sem bispo (ou presbítero)" (CATTANEO, 1997, p. 96). Não se pode achar normal que, na maior parte dos domingos, não haja celebração da eucaristia nas comunidades!

b. Que o Sínodo não se permita, no discernimento que será chamado a fazer desta situação, antepor o "direito de legislação" (no caso, prescrições relativas ao estado de vida dos padres e outras de instituição eclesiástica) ao "direito da graça” (no caso, o acesso à celebração da eucaristia, de instituição divina). Como ajustar estes dois legítimos direitos?

Estar-se-ia diante de uma situação deste gênero... - pondera Legrand, como já vimos (nota 37), - se a deficiência do número de cristãos capazes de viver o celibato, desde que estando aptos à ordenação, viesse a privar a Igreja deste ou daquele país dos padres necessários aos quais os cristãos têm direito, sem que a solidariedade de outras Igrejas locais pudesse remediar os graves danos que daí resultariam para a vida cristã (LEGRAND, 1979, p. 166).

Semelhantemente, e com maior razão, o "direito da graça" (no caso, o "direito sacramental") deveria prevalecer sobre o "direito de legislação" em questões menores como o tipo de formação, o exercício de profissão civil, um estilo de vida mais laical que sacral, etc. Evidentemente, todos estes elementos deverão ser devidamente equacionados, adaptando-os, porém, à comunidade e não o contrário.

c. A resposta que se der, a partir dos resultados do Sínodo para a Amazônia, a esta questão, terá certamente um impacto - que esperamos seja alvissareiro - para situações semelhantes em outras áreas da Igreja, tanto no Sul como no Norte do planeta. Pesa sobre o Sínodo para a Amazônia uma grande responsabilidade, pois se depositam nele grandes esperanças. Lobinger se perguntava por onde começar ou por onde começaria esta mudança, se no Norte, se no Sul. Pensava — e fazia dez considerações! — que as Igrejas do Norte deveriam dar o primeiro passo. Esperar para ver!

d. A introdução do ministério presbiteral em comunidades não elimina, antes valoriza, a rica, variada e multiforme ministerialidade local e laical. Também não desvaloriza nem dispensa os presbíteros - diocesanos e religiosos - que, por sua formação e experiência, por sua entrega radical, 
inclusive em virtude do carisma do celibato, poderão (e deverão!) assessorar e acompanhar e contribuir para a formação dos "presbíteros comunitários", assumir responsabilidades pastorais em nível diocesano e/ou em situações mais complexas e desafiadoras.

e. Lobinger insiste em que cada comunidade deve ser dotada de uma equipe de ministros ordenados (LOBINGER \& ALMEIDA, 2009). A intenção é exprimir o caráter colegial do ministério ordenado, garantir um rodízio na presidência das celebrações, prevenir o autoritarismo, coibir a centralização etc. Em um próximo trabalho, pensamos retomar esta ideia, alargando-a no sentido de uma equipe de animação da comunidade formada pelo ou pelos presbíteros da comunidade local, pelo ou pelos respectivos diáconos e diáconas (que esperamos sejam reintroduzidas, devidamente reinventadas, entre os ministérios ordenados) e por alguns leigos e leigas representativos da comunidade, eleitos por ela.

f. A eventual implementação dessa proposta de "presbíteros de comunidade" ou "equipes de ministros ordenados" deve obedecer a uma séria criteriologia, pedagogia e metodologia. Supõe, evidentemente, Igrejas locais e comunidades convictas da necessidade e possibilidade de dar esse passo, além de pessoas preparadas e dispostas a servir seus irmãos e irmãs através do ministério presbiteral na sua comunidade. Nem toda comunidade deve ou estará em condições de ter presbíteros comunitários, nem mesmo todas as dioceses. Em todo o caso, cada diocese deverá decidir sinodalmente a introdução de "padres comunitários" em sua área.

g. Todos somos chamados a rezar com os Padres Sinodais e demais participantes do Sínodo, o Adsumus:

Aqui estamos diante de vós, ó Espírito Santo Senhor nosso; aqui estamos cônscios dos nossos inúmeros pecados, porém unidos de modo particular em vosso nome. Vinde a nós e ficai conosco: dignai-vos penetrar em nossos corações. Sede guia das nossas ações, indicai-nos aonde devemos ir, e mostrai-nos o que devemos fazer, a fim de que, com o vosso auxílio, em tudo possa ser-vos agradável a nossa obra. Sede, vós só, o nosso inspirador, e dirigi as nossas intenções, pois só vós possuís um nome glorioso juntamente com o Pai e o Filho. Não permitais nunca que sejamos perturbadores da justiça, vós que sois a infinita equidade; não permitais que a ignorância nos induza ao mal, que as lisonjas nos curvem, que os interesses morais e materiais nos corrompam. Mas uni só a vós os nossos corações, fortemente, com o dom da vossa graça, a fim de que possamos ser em vós uma coisa só, e em nada nos 
afastemos da verdade. Assim como estamos unidos em vosso nome, possamos em cada obra nossa seguir os ditames da vossa piedade e da vossa justiça, a fim de que, hoje e sempre, o nosso juízo não se aparte do vosso, e no século futuro possamos conseguir o prêmio da nossa ação. Amém.

\section{Referências}

ALMEIDA, A. J. Os ministérios não-ordenados na Igreja Latino-Americana. São Paulo: Loyola, 1989.

ALMEIDA, A. J. Uma proposta madura à espera de uma resposta urgente. In: LOBINGER, F. Padres para amanhã: Uma proposta para comunidades sem eucaristia. São Paulo: Paulus, 2008. p. 9-75.

ALMEIDA, A. J.; LOBINGER, F. Equipes de ministros ordenados: Uma solução para a eucaristia nas comunidades. São Paulo: Paulus, 2009.

ALMEIDA, A. J. Novos ministérios: A necessidade de um salto à frente. São Paulo: Paulinas, 2013.

AUGUSTINUS. In Johannis. Disponível em: <http://www.documentacatholicaomnia.eu/03d/0354-

0430,_Augustinus,_In_Evangelium_Joannis_Tractatus_CXXIV_[Schaff],_EN.pdf>. Acesso em: 04 ago. 2019.

BANKS, R. Ordinamento e governo della Chiesa. In: G. F. HAWTHORNE, G. F.; MARTIN, R. P.; REID, D. G. (orgs.). Dizionario di Paolo e delle sue lettere. Cinisello Balsamo (MI): San Paolo, 1999.

BORRAS, A. Quand les prêtres viennent à manquer: Repères théologiques et canoniques en temps de précarité. Paris-Montréal: Médiaspaul 2017. p. 189-193.

CANOBBIO, G. Origine e senso dell'assioma "La Chiesa fa l'Eucaristia e l'Eucaristia fa la Chiesa”. In: CANOBBIO, G.; DALLA VECCHIA, F.; TONONI, R. (org.). Eucaristia e Chiesa. Brescia, Morcelliana, 2010. p. 211-232.

CATTANEO, E. I ministeri nella Chiesa Antica: Testi patristici dei primi tre secoli. Milano: Paoline, 1997.

CODINA, V. Riesgos y oportunidades del Sínodo de Amazonía, 2019. In: Centre d'estudis Cristianisme i Justícia edición 13/06/2019, Barcelona.

COMISSÃO TEOLÓGICA INTERNACIONAL [CTI]. O “sensus fidei” na vida da Iglesia (10 de junho de 2014). Disponível em:

<http://www.vatican.va/roman_curia/congregations/cfaith/cti_documents/rc_cti_20 140610_sensus-fidei_po.html>. Acesso em: 02 de set, 2019. 
CONCÍLIO VATICANO II. Lumen Gentium [LG]. Disponível em: http://www.vatican.va/archive/hist_councils/ii_vatican_council/documents/vatii_const_19641121_lumen-gentium_po.html. Ácesso em: 08 set. 2019.

CONCÍLIO VATICANO II. Sacrosanctum Concilium [SC]. Disponível em: vatican.va/archive/hist_councils/ii_vatican_council/documents/vat-

ii_const_19631204_sacrosanctum-concilium_po.html. Acesso em: 08 set. 2019.

CONCÍLIO VATICANO II. Presbyterorum Ordinis [PO]. Disponível em: http://www.vatican.va/archive/hist_councils/ii_vatican_council/documents/vatii_decree_19651207_presbyterorum-ordinis_en.html Acesso em: 08 set. 2019.

CONCÍLIO VATICANO II. Gaudium et Spes [GS]. Disponível em: http://www.vatican.va/archive/hist_councils/ii_vatican_council/documents/vatii_const_19651207_gaudium-et-spes_po.html Acesso em: 10 set. 2019.

CINCÍLIO VATICANO II. Orientalium Ecclesiarum [OE]. Disponível em: <http://www.vatican.va/archive/hist_councils/ii_vatican_council/documents/vatii_decree_19641121_orientalium-ecclesiarum_en.html>. Acesso em: 10 set. 2019.

CONFERÊNCIA NACIONAL DOS BISPOS DO BRASIL [CNBB]. Ministério e Celebração da Palavra. Brasília: Edições CNBB, 2019.

CONGAR, Y. Religion et institution. In: AA. VV., Théologie d'aujourd'hui et de demain. Paris: Cerf, 1967.

CONGAR, Y.- M. La "Ecclesia" o la comunidade cristiana, sujeto integral de la acción litúrgica. In: AA. VV. La liturgia después del Vaticano II. Madrid: Taurus, 1969. p. 279338.

DOMBOIS, H. Recht der Gnade: Ökumenisches Kirchenrecht v. II. Bielefeld: Luther Verlag, 1974.

DOMBOIS, H. Recht der Gnade: Ökumenisches Kirchenrecht v. III. Bielefeld: Luther Verlag, 1983.FAIVRE, A. I laici nelle origini della Chiesa. Cinisello Balsamo (MI): Paoline, 1986.

FLICHE, A.; MARTIN, V. Histoire de l'Église depuis les origines jusqu'à nos jours, I. L'Église primitive. Paris: Bloud \& Gay, 1946.

GIRARDI, L. “Commento". In: NOCETI, S.; REPOLE, R. (org.). Commentario ai Documenti del Vaticano II, 1, Sacrosanctum Concilium. Inter mirifica. Bologna: EDB, 2014.

GOMES, M. G. El sacerdocio y el ministerio de la eucaristía en las primeras comunidades cristianas. TdS 9, p. 41-118, 1977.

GRILLO, A. Actuosa participatio: Il vero fine della riforma liturgica. Pistis \& Práxis, v. 4, n. 2, p. 441-461, 2012. 
HIPÓLITO DE ROMA. Tradição apostólica: Liturgia e Catequese em Roma no século III. Petrópolis: Vozes, 1971.

HOFFMANN, J. "Grâce et institution selon Hans Dombois: une nouvelle approche du mystère de l'Église”. Revue des Sciences philosophiques et théologiques, Paris, n. 4, p. 645-647, 1968.

JOÃO PAULO II (promulgou). Catecismo da Igreja Católica [CAT]. São Paulo: Loyola, Vozes, Salesiana, Paulinas, Ave-Maria, Paulus, 1999.

JOÃO PAULO II, Pastores gregis 2003 [PG]. Disponível em: $<$ http://www.vatican.va/content/john-paul-

ii/pt/apost_exhortations/documents/hf_jp-ii_exh_20031016_pastores-gregis.html>. Acesso em: 08 set. 2019.

JOÃO PAULO II, Ordinatio sacerdotalis 1994 [OS]. Disponível em: <http://www.vatican.va/content/john-paul-ii/pt/apost_letters/1994/documents/hf_jpii_apl_19940522_ordinatio-sacerdotalis.html>. Acesso em: 09 set. 2019.

JUNGMANN, J. A. Missarum solemnia. Explication génétique de la Messe romaine, I. Paris: Aubier, 1950.

JUSTINO. Apologia I. Disponível em :

$<$ http://apologistascatolicos.com.br/obraspatristicas/Obras/PadresSecll/SaoJustino Martir/Apologial.html>. Acesso em: 07 set. 2019.

LEGRAND, H.-M., La présidence de l'Eucharistie selon la tradition ancienne. Spiritus, v. 18, p. 409-431, 1977.

LEGRAND, H. M. “Grâce et institution dans l'Église: les fondements théologiques du droit canonique”. In: AA. VV., Église: institution et foi, Bruxelles: Facultés universitaires Saint-Louis, 1979.

LEGRAND, H.-M. “Ministerios de la Iglesia local”. In: LAURET, B.; REFOULÉ, F. Iniciación a la práctica de la teología. Dogmática 2. Madrid: Cristiandad, 1985.

LÉON-DUFOUR, X. O partir do pão eucarístico segundo o Novo Testamento. São Paulo: Loyola, 1984.

LEONIS MAGNI. Opera Omnia. In: MIGNE, J.-P. (Éd.). Patrologia Latina vol. 54. Paris: 1846.

MAFFEIS, A. Creatura Verbi. Possibilità e limiti di una nozione ecclesiologica. In: NOCETI, S.; CIOLI, G.; CANOBBIO, G. Ecclesiam intelligere. Studi in onore di Severino Dianich. Bologna: EDB, 2012, p. 367-394.

MAZZA, E. La celebrazione eucaristica. Genesi del rito e sviluppo dell'interpretazione. Cinisello Balsamo (MI): San Paolo, 1996. 
MAZZA, E. dalla cena del Signore all'eucaristia dela Chiesa. In: BROUARD, M. Eucharistia, Enciclopedia eucaristia. Bologna: EDB, 2005. p. 103-110.

MONTINI, G. P. Adsumus, Domine Sancte Spiritus, adsumus. La preghiera nella sessione per la decisione giudiziale (can. 1609 § 3). Quaderni di diritto ecclesiale, v. 16, p. 164-194, 2003.

PAULO VI. Sacerdotalis Coelibatus 1967 [SacCoel]. Disponível em: <http://www.vatican.va/content/paul-vi/pt/encyclicals/documents/hf_pvi_enc_24061967_sacerdotalis.html>. Acesso em: 08 set. 2019.

PAULO VI. Inter Insigniores 1976 [II]. Disponível em: <http://www.vatican.va/roman_curia/congregations/cfaith/documents/rc_con_cfait h_doc_19761015_inter-insigniores_po.html>. Acesso em: 08 set. 2019.

PERROT, C. L'Eucaristia nel Nuovo Testamento. In: BROUARD, M. (ed.). Eucharistia. Enciclopedia dell'Eucaristia. Bologna: EDB, 2005.

ROSMINI, A. Las cinco llagas de la Santa Iglesia. Tratado dedicado al clero católico. Maracaibo: Ediciones Penínsola, 1968.

SCIMMI, M. Una lettura al passo con i tempi dele fonti sulle diacone. In: NOCETI, S. (org.), Diacone. Quale ministero per quale Chiesa? Brescia: Queriniana, 2017. p. 223-265.

SCIMMI, M. Le antiche diaconesse nella storiografia del XX secolo. Milano: Glossa, 2004.

SIMONELLI, C.; SCIMMI, M. Donne diacono? La posta in gioco. Padova: Messaggero, 2016.

SECRETARIA GERAL DO SÍNODO PARA A AMAZÔNIA. Documento Preparatório. Disponível em:

<http://www.sinodoamazonico.va/content/sinodoamazonico/pt/documentos/docu mento-preparatorio.pdf $>$. Acesso em 12 de setembro de 2019.

SECRETARIA GERAL DO SÍNODO PARA A AMAZÔNIA. Instrumentum laboris. Disponível em:

<http://www.sinodoamazonico.va/content/sinodoamazonico/pt/documentos/instru mentum-laboris-do-sinodo-amazonico.html>. Acesso em 13 de outubro de 2019.

SUESS, P. Verso il Sinodo panamazzonico / 1: il testamento di Francesco. Il Regno Attualità, v. 14, 2019.

SULLIVAN, F. A. Recent theological observations on magisterial documents and public dissent. Theological Studies, v. 58, p. 509-515, sept. 1997.

SULLIVAN, F. A. Capire e interpretare il magistero. Una fedeltà creativa. Bologna: EDB, 1997. 
TERTULIANO. De corona militis. Disponível em:

<http://www.tertullian.org/latin/de_corona.htm>. Acesso em: 07 set. 2019.

VAGAGGINI, C. L'ordinazione delle diaconesse nella tradizione greca e bizantina. Orientalia christiana periódica, v. 40, p. 145-189, 1974.

RECEBIDO: $12 / 09 / 2019$

APROVADO: $27 / 10 / 2019$
RECEIVED: 09/12/2019

APPROVED: $10 / 27 / 2019$ 